\title{
Packed-bed sensible thermal energy storage system using demolition wastes for concentrated solar power plants
}

\author{
Burcu Koçak ${ }^{1}$, and Halime Paksoy ${ }^{2, *}$ \\ ${ }^{1}$ Çukurova University, Central Research Laboratory (CUMERLAB), Adana, Turkey \\ ${ }^{2}$ Faculty of Arts and Sciences, Chemistry Department, Cukurova University, Adana, Turkey
}

\begin{abstract}
This paper presents a study on development of a packed-bed storage system for CSP applications. In this system, demolition wastes from urban regeneration projects in Turkey has been investigated as potential STESM for cost effective storage systems. Schumann's two-phase onedimensional model was used to evaluate the optimal design parameters. Effect of operational and geometrical design parameters such as mass velocity, porosity, aspect ratio of packed bed, packing diameter were assessed on storage performance. The system showed the best performance with low bed void fraction, low mass flow rate and low $\mathrm{Re}_{\mathrm{p}}$.
\end{abstract}

\section{Introduction}

Solar thermal energy has a huge potential as renewable energy source. In addition to heating and cooling use of solar thermal, electricity can be generated through a thermal cycle by concentrated solar power (CSP) plants. CSP technologies concentrate sun light and heat transfer fluid (HTF) in the temperature range between $250^{\circ} \mathrm{C}-1000^{\circ} \mathrm{C}$. Solar power towers, parabolic trough collectors, dish stirling reflectors and linear Fresnel collectors are some of the main components in CSP used for harnessing solar energy. Together with these technologies, sustainable and cost-effective storage systems to ensure continuous and efficient power production are needed.

Sensible thermal energy storage (STES) systems provide solutions to improve potential of CSP plants for both short-term and long-term storage. Parameters for system design, optimization and choice of storage medium depend on CSP technologies and operating temperature range.

Several sensible thermal energy storage materials (STESM) have been tested for CSP applications. The properties of STESMs which can be used for CSP applications are given in Table 1. Among these are molten salt, alumina, rock and high temperature concrete are the most preferred ones. There are some limitations of these STESMs. Molten salts can be corrosive and can be degraded above $600^{\circ} \mathrm{C}$. Rock and concrete are not considered sustainable, since they depend on depletion of natural materials. In addition, finding uniform sized rock particles for efficient packing ratio may be problematic and expensive. 
Table 1. Properties of STESMs that can be used for CSP applications

\begin{tabular}{lcccc}
\hline Materials & $\begin{array}{c}\text { Density, } \rho \\
\left(\mathrm{kg} / \mathrm{m}^{3}\right)\end{array}$ & $\begin{array}{c}\text { Thermal Conductivity, } \\
\mathrm{k}(\mathrm{W} / \mathrm{mC})\end{array}$ & $\begin{array}{c}\text { Specific Heat, Cp } \\
(\mathrm{kJ} / \mathrm{kgK})\end{array}$ & Ref. \\
\hline $\begin{array}{l}\text { Solar Salt } \\
\text { (NaNO }\end{array} \mathrm{KNO}_{3}$ 0.6:0.4) & 1900 & 0.59 & 1.575 & {$[18]$} \\
Silica & 2500 & 0.1 & 0.90 & {$[10]$} \\
Gneiss Rock & 2740 & 3.0 & 0.82 & {$[15]$} \\
Alumina balls & 3350 & 30 & 0.90 & {$[16]$} \\
Basalt & 2644 & 2.08 & 0.77 & {$[17]$} \\
Cofalit & 3120 & 2.1 & 0.80 & {$[18]$} \\
Concrete & 2200 & 1.5 & 0.85 & {$[19]$} \\
Coal Fly Ash & 2600 & 1.3 & $0.7-1.3$ & {$[18]$} \\
\hline
\end{tabular}

In this study, demolition wastes from urban regeneration projects in Turkey has been investigated as potential STESM [1]. Valorization of these demolition wastes can help efficient utilization of solar energy and reduce solid wastes, which is becoming a huge problem in metropolitan areas. Using abundant and cheap STESM with high energy density is very important for cost-effective CSP applications.

Although using cheap storage material is important criteria, there are a lot of design parameters that effect the storage performance. According to Marti et al [14], mass flow, inlet temperature, particle diameter, bed void fraction and packed bed dimensions are main operational and geometrical parameters that need to be determined for storage design. Khan et al [5] have determined that fluid velocity and particle dimensions are effective on solid storage system behavior in CSP plants. Elouali et al [2] investigated the influence of different design parameters on packed-bed performance. Results showed that decrease of particle size and increase of the mass velocity of HTF increase the storage performance of packed-bed. Lugolole et al [6] also performed a study to evaluate the effect of HTF velocity and particle diameter. The system with small pebbles of $10.5 \mathrm{~mm}$ diameter and low HTF velocity of $4 \mathrm{ml} / \mathrm{s}$ showed the best storage performance. Tiskatine et al [4] analysed different rock types to determine their potential as STESM in CSP plants. Results showed that physical and mechanical properties of dolerite, granodiorite, hornfels, gabbro and quarzitic sandstone are the most suitable ones for high temperature applications.

Bataineh and Gharaibeh [7] studied optimum design parameters for solid sensible storage system for a parabolic trough power plant. For constant storage tank volume, height to diameter ratio of storage tank did not show a big effect on storage performance. Buscemi et al [3] designed concrete thermal energy storage system integrated to Linear Fresnel Collectors for a pasta factory in Southern Italy. Stored energy was used in the pasta drying process with $87 \%$ efficiency.

Zhao et al [8] developed a one-dimensional enthalpy-based dispersion-concentric (D-C) model to investigate efficient tank size of packed-bed system for concentrated solar power with a storage capacity of 2000 MWht. Nandi et al [9] developed three-dimensional numerical computational fluid dynamics (CFD) model to optimize design parameters of thermocline thermal energy storage system.

In this study, the aim is to investigate the optimum design parameters of a packed-bed storage system using demolition waste as STESM for CSP applications. Schumann's twophase one-dimensional model was used to evaluate the effects of parameters such as mass velocity, porosity, aspect ratio of packed bed, packing diameter on storage performance. 


\begin{tabular}{|ll|}
\hline Nomenclature & \\
$\mathrm{Cp}$ & Specific heat $\left(\mathrm{Jkg}^{-1} \mathrm{~K}^{-1}\right)$ \\
$\mathrm{D}_{\mathrm{p}}$ & Diameter of particle $(\mathrm{m})$ \\
$\mathrm{D}_{\mathrm{T}}$ & Diameter of tank $(\mathrm{m})$ \\
$\mathrm{f}$ & Fluid \\
$\mathrm{h}_{\mathrm{v}}$ & Heat transfer coefficient $\left(\mathrm{Wm}^{-2} \mathrm{~K}^{-1}\right)$ \\
$\mathrm{k}_{\mathrm{f}}$ & Fluid thermal conductivity $\left(\mathrm{Wm}^{-1} \mathrm{~K}^{-1}\right)$ \\
$\mathrm{m}$ & Mass flow rate $\left(\mathrm{kgs}^{-1}\right)$ \\
$\mathrm{p}$ & Particle \\
$\mathrm{s}$ & Solid \\
$\mathrm{t}$ & Time (s) \\
$\mathrm{T}$ & Temperature $\left({ }^{\circ} \mathrm{C}\right)$ \\
$\mathrm{T}_{\text {in }}$ & Inlet Temperature $\left({ }^{\circ} \mathrm{C}\right)$ \\
$\mathrm{T}_{\mathrm{o}}$ & Outlet Temperature $\left({ }^{\circ} \mathrm{C}\right)$ \\
$\mathrm{u}_{\mathrm{sup}}$ & Superficial fluid velocity $\left(\mathrm{ms}^{-1}\right)$ \\
$\mathrm{v}_{\mathrm{f}}$ & velocity $\left(\mathrm{mms}{ }^{-1}\right)$ \\
$\eta_{C}$ & Charging efficiency $(\%)$ \\
$\rho$ & Density $\left(\mathrm{kgm}{ }^{-3}\right)$ \\
$\mu$ & Dynamic viscosity $\left(\mathrm{kgm}^{-1} \mathrm{~s}^{-1}\right)$ \\
$\varepsilon$ & Bed void fraction \\
$\mathrm{Re}_{\mathrm{p}}$ & Reynolds Particle \\
& \\
\hline
\end{tabular}

\section{Packed Bed Storage System}

\subsection{Design Parameters}

The packed bed TES system will be investigated numerically under different operating conditions. In this design, the packed bed column will be a cylindrical storage tank of $1.0 \mathrm{~m}$ diameter and $3.0 \mathrm{~m}$ height with aspect ratio of 3. Synthetic thermal oil (Therminol 66) will be used as HTF for storing heat up to $350{ }^{\circ} \mathrm{C}$ for CSP plants. Properties of Therminol 66 oil varying with temperature and temperature dependent correlations are given in Equation 1, 2 and 3.

$$
\begin{aligned}
& \rho_{f}=-0.614254 T-0.000321 T^{2}+1020.62 \\
& C p_{f}=0.003313 T+0.0000008970785 T^{2}+1.496005 \\
& k_{f}=-0.000033 T-0.00000015 T^{2}+1.496005
\end{aligned}
$$

Demolition wastes from an urban regeneration project in Turkey will be assessed as STESM with a heat capacity of $3200 \mathrm{~kJ} / \mathrm{m}^{3} \mathrm{~K}$ [1]. The ranges of the operating parameters of the packed-bed system is given in Table 2 . 
Table 2. TES design parameters and ranges

\begin{tabular}{lc}
\hline Design Parameters & Range of Parameters \\
\hline Inlet Temperature, ${ }^{\circ} \mathrm{C}$ & $200-350$ \\
Fluid Velocity, $\mathrm{mm} / \mathrm{s}$ & $0.5-3$ \\
Bed void fraction & $0.2-0.6$ \\
Packing Diameter $\left(\mathrm{D}_{\mathrm{T}} / \mathrm{D}_{\mathrm{p}}\right)$ & $20-40$ \\
Density of particle, $\mathrm{kg} / \mathrm{m}^{3}$ & 2190 \\
Specific heat of particle, $\mathrm{Jkg}^{1} \mathrm{~K}^{-1}$ & 1340 \\
Reynolds Particle, $\mathrm{Re}_{\mathrm{p}}$ & $15-150$ \\
\hline
\end{tabular}

\subsection{Numerical Analysis}

One-dimensional two-phase Schumann's model was used to define design parameters of a packed-bed storage system for CSP applications. Following assumptions were considered in modelling:

- Heat conduction occurs only in axial direction

- No heat exchange between particles

- Heat exchange occurs from particles to HTF

- The system is well insulated and there is no heat loss

Governing equations can be written for solid and liquid phases as given in Equation 4 and 5 , respectively $[11,12]$ :

$$
\begin{array}{r}
\varepsilon \rho_{f} C p_{f} \frac{\partial T_{f}}{\partial t}+\varepsilon u_{\text {sup }} \rho_{f} C p_{f} \frac{\partial T_{f}}{\partial x}=h_{v}\left(T_{s}-T_{f}\right) \\
(1-\varepsilon) \rho_{s} C p_{s} \frac{\partial T_{s}}{\partial t}=h_{v}\left(T_{f}-T_{s}\right)
\end{array}
$$

Where $\rho_{\mathrm{f}}$ and $\rho_{\mathrm{s}}$ are density of fluid and solid phase and $C \mathrm{p}_{\mathrm{f}}$ and $C \mathrm{p}_{\mathrm{s}}$ are specific heat of fluid and solid phase, respectively. $\mathrm{u}_{\text {sup }}$ is superficial fluid velocity inside the packed bed, calculated based on porosity in Equation 6 [13]:

$$
u_{\text {sup }}=\frac{\dot{m}}{\rho_{f} \pi \frac{\left(D_{T}\right)^{2}}{4} \varepsilon}
$$

Volumetric heat transfer coefficient $\mathrm{h}_{\mathrm{v}}$ are given by Equation 7 where particle Reynolds number is greater than 15 [10]:

$$
h_{v}=\frac{6(1-\varepsilon) k_{f}\left[2.0+1.1 * \operatorname{Pr}^{\frac{1}{3}} * R e_{p}{ }^{0.6}\right]}{D_{S}^{2}}
$$

According to Cardenas et al [20], Prandtl number (Pr) is calculated by Equation 8 .

$$
\operatorname{Pr}=\mu_{f} C p_{f} / k_{f}
$$

Reynolds number based on particle diameter $\left(\mathrm{Re}_{\mathrm{p}}\right)$ indicates the flow regime in the storage tank and defined as [10]:

$$
R e_{p}=\frac{\rho_{f} u_{\text {sup }} D_{p}}{\mu_{f} \varepsilon}
$$




\section{Results and Discussion}

The effects of operating parameters on thermocline storage system efficiency is defined by Nandi et al [9] based on the first law of thermodynamic. According to this, charging and discharging efficiency at any time can be found from Equation 10.

$$
\eta=\frac{\left(m_{f} C_{p f}+m_{s} C_{p s}\right)\left|T_{a v g}-T_{0}\right|}{\left(\dot{m}_{f}\right) C_{p f} t\left|T_{i n}-T_{0}\right|}
$$

Table 3 shows the effect of HTF velocity on charging efficiency at t:30 minutes with 0.45 bed void fraction and $250{ }^{\circ} \mathrm{C}$ inlet fluid temperature. Charging efficiency drops dramatically over $1.5 \mathrm{~mm} / \mathrm{s}$ velocity. Unsteady laminar flow starts when Rep is higher than 150 [14] and for the system analysed here, Rep is close to 150 at $3.0 \mathrm{~mm} / \mathrm{s}$ velocity. As seen in Figure 1, stratification of thermocline starts to be destroyed after $1.5 \mathrm{~mm} / \mathrm{s}$. Lower velocity shows better stratification and charging efficiency. On the other hand, it increases total charging time.

Table 3. Effect of velocity on charging efficiency and $\mathrm{Re}_{\mathrm{p}}$

\begin{tabular}{|c|c|c|}
\hline Velocity, $\mathrm{v} f, \mathrm{~mm} / \mathrm{s}$ & Charging efficiency, & $\eta_{C}, \quad \operatorname{Re}_{p} @ 250{ }^{\circ} \mathrm{C}$ \\
\hline 0.5 & 98.8 & 22 \\
\hline 1.0 & 98.3 & 45 \\
\hline 1.5 & 97.9 & 67 \\
\hline 2.0 & 91.9 & 90 \\
\hline 2.5 & 80.6 & 112 \\
\hline 3.0 & 69.4 & 135 \\
\hline
\end{tabular}

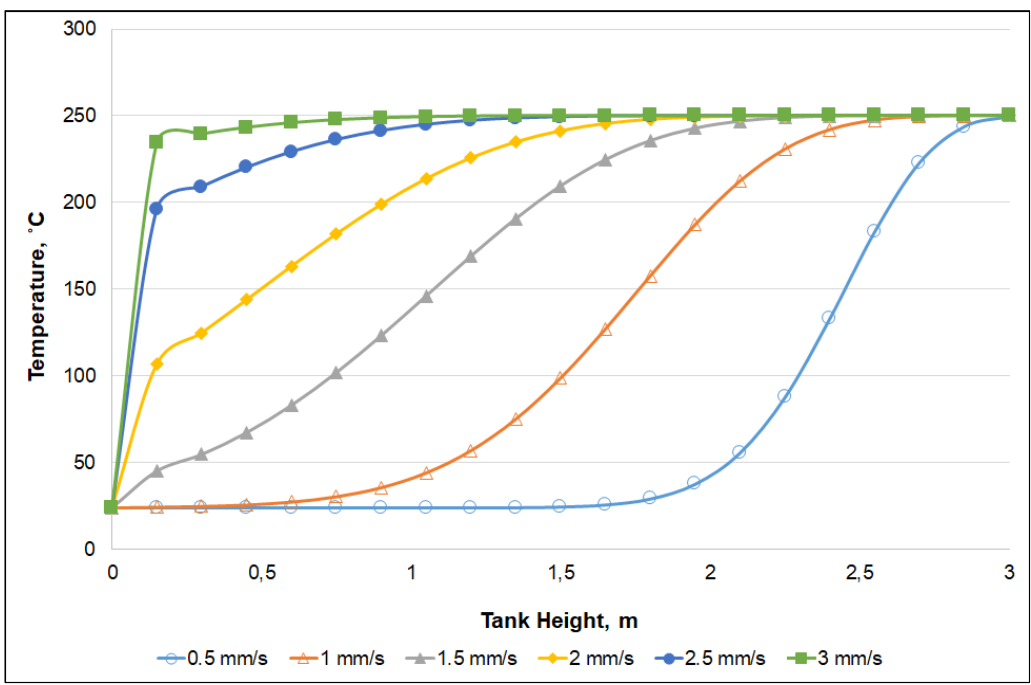

Figure 1. Change in stratification with velocity

According to Bruch et al [10], choosing the ratio of diameter of the tank to the characteristic diameter of packing is an important design parameter to have negligible wall effects. Figure 2 shows the effect of $\mathrm{D}_{\mathrm{T}} / \mathrm{D}_{\mathrm{P}}$ ratio on system performance. At constant bed void 
fraction, changing $\mathrm{D}_{\mathrm{T}} / \mathrm{D}_{\mathrm{P}}$ ratio did not show significant effect on both storage efficiency and stratification behaviour. However, it is expected that increasing $\mathrm{D}_{\mathrm{T}} / \mathrm{D}_{\mathrm{P}}$ ratio by decreasing particle diameter can decrease bed void fraction and $\mathrm{Re}_{\mathrm{p}}$. Thus, the system efficiency is also expected to increase.

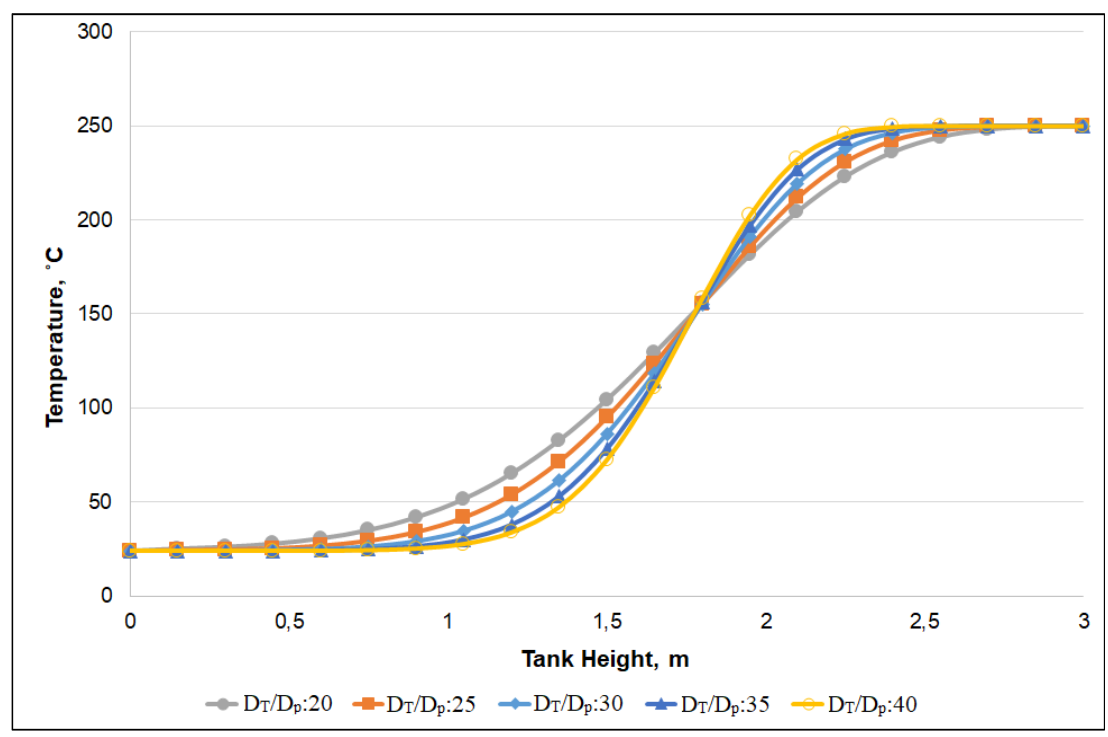

Figure 2. Change in stratification with the ratio of tank diameter to packing diameter $\left(\mathrm{D}_{\mathrm{T}} / \mathrm{D}_{\mathrm{p}}: 20\right)$

As decreasing the packing diameter would also decrease, bed void fraction. storage tank can be filled with more packing material. Figure 3 shows the effect of bed void fraction on stratification behaviour. When the bed void fraction decreases, stratification behaviour starts to enhance. The effect of bed void fraction on charging efficiency is shown in Table 4. Although storage efficiency increases with decreasing bed void fraction, the effect on efficiency is less.

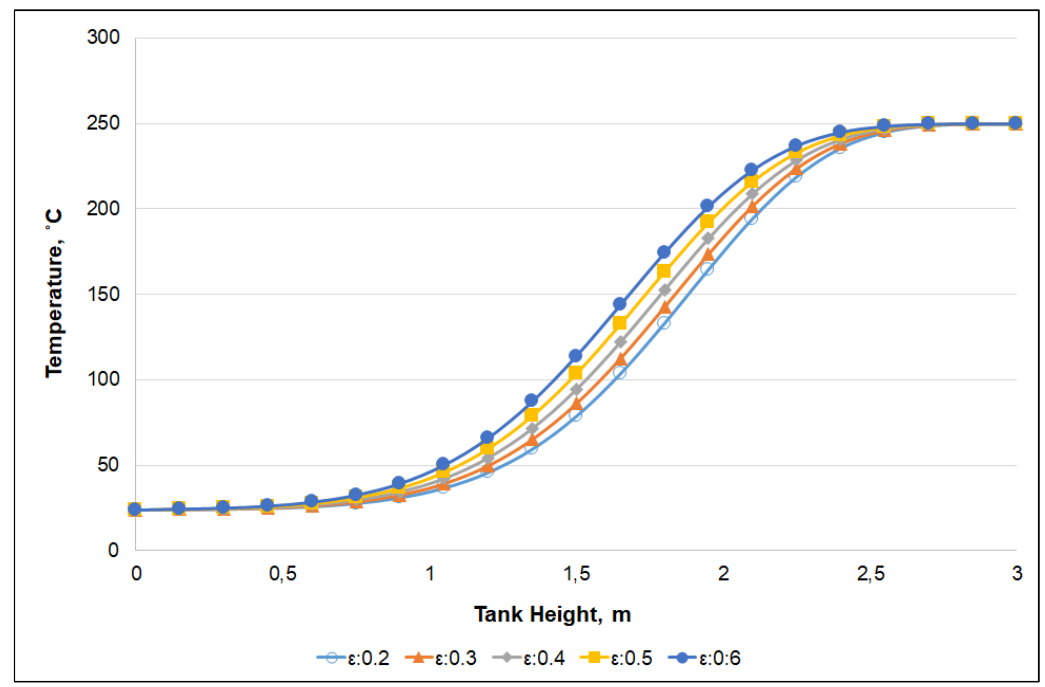

Figure 3. Change in stratification with bed void fraction 
Table 4. Effect of bed void fraction on charging efficiency and $\mathrm{Re}_{\mathrm{p}}$

\begin{tabular}{cc}
\hline Bed void fraction, $\varepsilon$ & Charging efficiency, $\eta_{C}, \%$ \\
\hline 0.2 & 98.9 \\
0.3 & 98.8 \\
0.4 & 98.5 \\
0.5 & 98.4 \\
0.6 & 98.3 \\
\hline
\end{tabular}

Gibb et al [21] defined the total system energy storage capacity as sum of solid phase and sum of the components. Based on this definition, total stored energy is calculated by Equation (11) and (12).

$$
\begin{gathered}
\mathrm{Q}_{\text {stored }}=\mathrm{Q}_{\text {solid phase }}+\mathrm{Q}_{\text {components }} \\
Q_{\text {stored }}=m_{s} C p_{s}\left(T_{\text {avg }}-T_{t: 0}\right)+m_{f} C p_{f}\left(T_{\text {avg }}-T_{t: 0}\right)
\end{gathered}
$$

The change in accumulated stored energy by solid and fluid phases with time is given in Figure 4. Total energy stored during charging step, which reaches steady state after $100 \mathrm{~min}$, is $376 \mathrm{kWh}$.

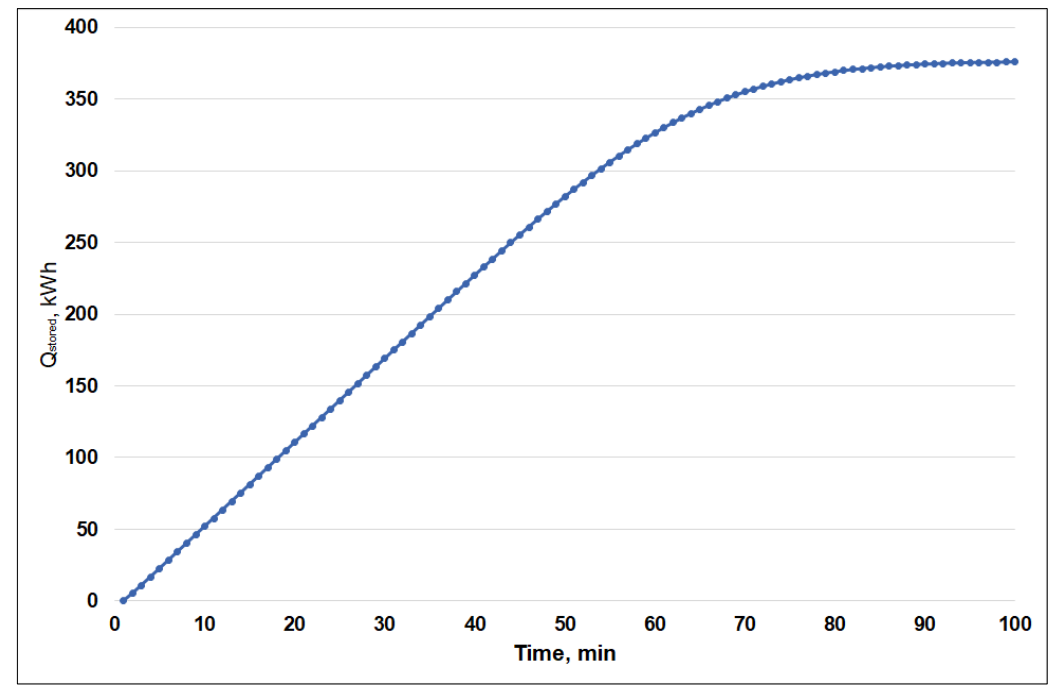

Figure 4. The change of accumulated stored energy with time

\section{Conclusion and Outlook}

The packed bed storage system for CSP plants was numerically studied by using Schumann's model. In this system, demolition wastes as STESM and Therminol 66 as HTF was assessed. Mass velocity, bed void fraction, packing diameter and Reynolds number were defined critical design parameters. When the variable design parameters were evaluated by numerical model, it was found that laminar flow regime with low Rep and low mass velocity 
are the main criteria to reach high efficiency and smooth thermocline profile. In this study, the best storage performance was obtained when fluid velocity was $0.5 \mathrm{~mm} / \mathrm{s}$ and the ratio of tank diameter to packing diameter $\left(\mathrm{D}_{\mathrm{T}} / \mathrm{D}_{\mathrm{P}}\right)$ was 40 . Storage efficiency reached to $98.5 \%$ with bed void fractions up to 0.4. In further studies, effects of pressure drop, wall effect and temperature change on the system efficiency will be investigated. Moreover, scale-up of the packed bed storage system based on real operational CSP parameters need to be considered for future studies.

\section{Acknowledgements}

The authors would like to acknowledge the support provided by Çukurova University BAP Project No: FUA-2018-6365.

\section{References}

1.B. Koçak, H. Paksoy, Using demolition wastes from urban regeneration as sensible thermal energy storage material, International Journal of Energy Research, In press.

2. A. Elouali, T. Kousksou, T. El Rhafiki, S. Hamdaoui, M. Mahdaouic, A. Allouhi, Y. Zeraouli, Physical models for packed bed: Sensible heat storage systems, Journal of Energy Storage 23 69-78 (2019)

3. A. Buscemi, D. Panno, G. Ciulla, M. Beccali, V. Lo Brano, Concrete thermal energy storage for linear Fresnel collectors: Exploiting the South Mediterranean's solar potential for agri-food processes, Energy Conversion and Management 166 719-734 (2018)

4. R.Tiskatine, R.Oaddi, R.Ait El Cadi, A.Bazgaou, L.Bouirden, A.Aharoune, A.Ihlal, Suitability and characteristics of rocks for sensible heat storage in CSP plants, Solar Energy Materials and Solar Cells Volume 169, 245-257 (2017)

5. M. Khan, N. M. S. Hassan, A. K. Azad, Investigation of thermal energy storage systems in concentrated solar power, Energy Procedia 160, 738-745, (2019)

6. R. Lugolole, A. Mawire, K.A. Lentswe, D. Okello, K. Nyeinga, Thermal performance comparison of three sensible heat thermal energy storage systems during charging cycles, Sustainable Energy Technologies and Assessments 30, 37-51, (2018)

7. K. Bataineh, A. Gharaibeh, Optimal design for sensible thermal energy storage tank using natural solid materials for a parabolic trough power plant, Solar Energy 171, 519-525, (2018)

8. B. Zhao, M. Cheng, C. Liu, Z. Dai, An efficient tank size estimation strategy for packedbed thermocline, thermal energy storage systems for concentrated solar power, Solar Energy 153, 104-114, (2017)

9. B. Rahul Nandi, S. Bandyopadhyay, R. Banerjee, Numerical modeling and analysis of dual medium thermocline thermal energy storage, Journal of Energy Storage 16, 218-230, (2018)

10. A. Bruch, J.F. Fourmigue and R. Couturier, "Experimental and numerical investigation of a pilot-scale thermal oil packed bed thermal storage system for CSP power plant", Solar Energy, 105, 116-125, (2014)

11.K.A.R. Ismail, R. Stuginsky Jr., "A parametric study on possible fixed bed models for pcm and sensible heat storage", Applied Thermal Engineering, 19, 757-788, (1999) 
12.A. Mawire, M. McPherson, R.R.J. van den Heetkamp and S.J.P. Mlatho, "Simulated performance of storage materials for pebble bed thermal energy storage (TES) systems", Applied Energy, 86, 1246-1252, (2009)

13.A. Bruch, S. Molina, T. Esence, J.F. Fourmigu and R. Couturier, "Experimental investigation of cycling behaviour of pilot-scale thermal oil packed-bed thermal storage system", Renewable Energy, 103, 277-285, (2017)

14. J. Marti, L. Geissbühler, V. Becattini, A. Haselbacher and Aldo Steinfeld, "Constrained multi-objective optimization of thermocline packed-bed thermal-energy storage", Applied Energy, 216, 694-708, (2018)

15. Y. Jemmal,N. Zari,M. Maaroufi,"Thermophysical and chemical analysis of gneiss rock as low cost candidate material for thermal energy storage in concentrated solar power plants”, Solar Energy Materials \& Solar Cells, 157, 377-382 (2016).

16. M. Cascetta, G. Cau, P. Puddu, F.Serra, "A study of a packed bed thermal energy storage device: test rig, experimental and numerical results", Energy Procedia, 81, 987-994, (2015).

17. R. Tiskatine, A. Aharoune, L. Bouirden, A. Ihlal, "Identification of suitable storage materials for solar thermal power plant using selection methodology", Applied Thermal Engineering, 117, 591-608, (2017).

18. F. Motte, Q. Falcoz, E. Veron, X. Py, “Compatibility tests between Solar Salt and thermal storage ceramics from inorganic industrial wastes", Applied Energy, 155, 14-22, (2015).

19. L. Prasad and P. Muthukumar, "Design and optimization of lab-scale sensible heat storage prototype for solar thermal power plant application”, Solar Energy, 97, 217-229, (2013).

20. B. Cardenas, T. R. Davenne, J. Wang, Y. Ding, Y. Jin, H. Chen, Y. Wu and S. D. Garvey, "Techno-economic optimization of a packed-bed utility-scale energy storage", Applied Thermal Engineering, 153, 206-220, (2019).

21. D. Gibb, M. Johnson, J. Romaní, J. Gasia, L.F. Cabeza, A. Seitz, "Process integration of thermal energy storage systems - evaluation methodology and case studies", Applied Energy, 230, 750-760, (2018). 